\title{
Bone Metastasis Targeting Peptide-11
}

National Cancer Institute

\section{Source}

National Cancer Institute. Bone Metastasis Targeting Peptide-11. NCI Thesaurus. Code C82370.

A peptide that mimics naturally occurring interleukin-11 (IL-11) with interleukin receptor binding activity. Upon administration, bone metastasis targeting peptide-11 (BMTP-11) binds to interleukin-11 receptor alpha (IL-11Ra) BMTP-11. This agent might be used to deliver therapeutic agents specifically to IL-11Ra-expressing tumor cells while sparing normal cells. IL-11Ra is a cell surface receptor that may be overexpressed by osteosarcoma cells and by prostate cancer cells in prostate cancer bone metastases. 